\title{
Effect of dietary phosphorus on intestinal phosphorus absorption in growing Holstein steers
}

\author{
X. Feng, ${ }^{* 1}$ E. Ronk, ${ }^{*}$ M. D. Hanigan, ${ }^{*}$ K. F. Knowlton, ${ }^{*}$ H. Schramm,† and M. McCann \\ *Department of Dairy Science, \\ †Virginia Maryland Regional College of Veterinary Medicine, and \\ ‡Department of Animal and Poultry Sciences, Virginia Polytechnic Institute and State University, Blacksburg 24061
}

\begin{abstract}
The effect of dietary $\mathrm{P}$ intake on intestinal $\mathrm{P}$ absorption was evaluated in growing Holstein steers. Diets varying in $\mathrm{P}$ content $(0.15,0.27,0.36$, and $0.45 \%$, DM basis) were fed to 8 steers $(174 \pm 10 \mathrm{~kg}$ of $\mathrm{BW})$ fitted with permanent duodenal and ileal cannulas in a replicated $4 \times 4$ Latin square with 14 -d periods. Ytterbium-labeled corn silage and cobalt-EDTA were used as particulate and liquid phase markers, respectively, to measure digesta flow. Duodenal and ileal samples and spot urine samples were collected every $9 \mathrm{~h}$ from d 11 to 14. Total fecal collection was conducted on d 11 to 14 with fecal bags. Blood samples were collected from the coccygeal vessel on d 14. Feed, digesta, and fecal samples were analyzed for total $\mathrm{P}$ and inorganic P. Data were analyzed using PROC GLIMMIX in SAS with a model including treatment, square, period, and interaction of treatment and square. Preplanned contrasts were used to evaluate linear and quadratic treatment effects. Results were reported as least squares means. Dry matter intake $($ mean $=4.90 \mathrm{~kg} / \mathrm{d}, 2.8 \%$ of $\mathrm{BW})$ and apparent DM digestibility $($ mean $=78.1 \%)$ were unaffected by treatment. Duodenal and ileal flow of total $\mathrm{P}$ increased linearly with increasing $\mathrm{P}$ intake (13.4, 18.5, 23.0, and $27.4 \mathrm{~g} / \mathrm{d} ; 6.80,7.87,8.42$, and 10.4 $\mathrm{g} / \mathrm{d})$. Increasing $\mathrm{P}$ intake increased the quantity of $\mathrm{P}$ absorbed from the small intestine linearly $(6.96,11.1$, 14.6, and $17.2 \mathrm{~g} / \mathrm{d}$ ), but absorption efficiency was unchanged $($ mean $=59.6 \%)$. Phosphorus was absorbed on a net basis from the large intestine, but this was not affected by treatment and was a small proportion of total $\mathrm{P}$ absorption. Blood inorganic $\mathrm{P}$ increased linearly with increased dietary $\mathrm{P}(4.36,6.31,7.68$, and $8.5 \mathrm{mg} / \mathrm{dL})$ and salivary $\mathrm{P}$ secretion was unchanged $($ mean $=5.79$ $\mathrm{g} / \mathrm{d}$ ), suggesting that rumen function was prioritized during short-term $\mathrm{P}$ deficiency. These data showing an absence of change in absorption efficiency and salivary
\end{abstract}

Received November 23, 2014

Accepted January 31, 2015.

${ }^{1}$ Corresponding author: yangxin@vt.edu
$\mathrm{P}$ secretion in the face of short-term $\mathrm{P}$ deficiency may be used to improve published models of $\mathrm{P}$ digestion, absorption, and metabolism.

Key words: phosphorus, digestion and absorption, Holstein steer

\section{INTRODUCTION}

Manure $\mathrm{P}$ contamination of surface water can impair the growth and survival of aquatic species. The strong relationship between dietary $\mathrm{P}$ and manure $\mathrm{P}$ content in most species (Erickson et al., 1999; Knowlton and Herbein, 2002; Wu et al., 2003) makes dietary nutrient management a useful approach to reduce the environmental impact of livestock farms, but also makes it important to have detailed knowledge of the fate of dietary $\mathrm{P}$ and its utilization in the digestive tract. In ruminants, absorption of $\mathrm{P}$ is modulated by endocrine and nutritional factors such as mineral content of the diet, $\mathrm{P}$ content of the diet, and the forms of $\mathrm{P}$ in the diet (Field et al., 1983; Scharrer, 1985; Care, 1994).

In both ruminants and nonruminants, the major site for $\mathrm{P}$ absorption is the small intestine. Nonruminants have 2 mechanisms of $\mathrm{P}$ absorption: a vitamin $\mathrm{D}$-dependent active transport, which dominates at low concentrations of $\mathrm{P}$ in the intestinal contents, and passive absorption, which plays an important role with greater dietary P supply (Wasserman and Taylor, 1976; NRC, 2001). Whether similar processes are dominant in ruminants is unclear. The general form of the relationship between supply and absorption of $\mathrm{P}$ is that increasing $\mathrm{P}$ flow decreases absorption efficiency, suggesting that a carrier-mediated system might be involved, at least in sheep (Scott et al., 1984). Care et al. (1980) indicated active transport was involved in $\mathrm{P}$ absorption in sheep based on the evidence that total $\mathrm{P}$ absorbed reached plateau when the $\mathrm{P}$ content of a perfusate was increased to $15 \mathrm{mmol} / \mathrm{L}$. Phosphorus absorption in small intestine is also related to age, physiological state, and unexplained animal-to-animal variation (Field et al., 1983).

Most of the inorganic P (Pi) absorbed is from the small intestine, though at higher intake of $\mathrm{P}$ some net 
absorption of $\mathrm{Pi}$ also occurs from the large intestine (Care, 1994). Net absorption of $\mathrm{P}$ from the large intestine in sheep ranges from 2 to $30 \%$ of the $\mathrm{P}$ flow entering the large intestine (Breves and Schroder, 1991). The absorption of Pi from the large intestine is concentration dependent and may change from net absorption to net secretion with higher $\mathrm{P}$ intake (Breves et al., 1985). Holler et al. (1988) reported net Pi secretion into the colon with a Pi-free infusate into the colon of sheep and net $\mathrm{Pi}$ uptake with an infusate containing 2.5 to 6.5 $\mathrm{mmol} / \mathrm{L}$ of $\mathrm{Pi}$. In addition, $\mathrm{Pi}$ can be released within the large intestine by microbial degradation of phytate as occurs in the rumen (Ray et al., 2013). The effect of dietary $\mathrm{P}$ on absorption of $\mathrm{P}$ from the small and large intestines of cattle is rarely reported but is important in efforts to optimize $\mathrm{P}$ feeding and reduce $\mathrm{P}$ runoff from farms. Our objective was to estimate effects of dietary $\mathrm{P}$ on intestinal $\mathrm{P}$ absorption in growing Holstein steers.

\section{MATERIALS AND METHODS}

The trial was conducted at the Virginia Tech Dairy Center under the approval of the Institutional Animal Care and Use Committee, Virginia Polytechnic Institute and State University, Blacksburg (13-006-DASC).

\section{Animals}

Holstein steer calves (3 to 4 mo old) were purchased directly from a commercial dairy farm. Before transport, steers were vaccinated with Bovi-shield Gold and Ultrabac-7 (Zoetis Inc., Florham Park, NJ) and tested for bovine viral diarrhea with an ear notch sample. Steers were halter trained and then dehorned using cauterization. After the calves fully recovered from dehorning, T-shaped cannulas were inserted to the duodenum and ileum. Cannulas were made from Tygon (barrel part) and vinyl tubing (flange part), and the pieces were connected using cyclohexane. The duodenal cannula was placed $\sim 5 \mathrm{~cm}$ from the pyloric sphincter, and the ileal cannula was placed $\sim 5 \mathrm{~cm}$ from the ileo-cecal junction. Surgeries were done with the animal in lateral recumbent position using intravenous anesthesia. Steers recovered fully from surgery before initiation of the experiment. Throughout the experiment, no blockage was encountered in either the duodenal or ileal cannulas, and no evidence was found of the cannulas adding significant resistance to digesta flow.

\section{Experimental Design and Sampling}

Eight duodenally and ileally cannulated Holstein steers averaging $173.7 \pm 9.5 \mathrm{~kg}$ at $6 \mathrm{mo}$ of age were used in a replicated $4 \times 4$ Latin square design with 14-d periods. The basal diet was formulated to meet all nutrient requirements except P (NRC, 1996). Assuming the same $\mathrm{P}$ requirements for these steers as for growing beef steers $(16 \mathrm{mg}$ of $\mathrm{P} / \mathrm{kg}$ of $\mathrm{BW}$ for maintenance plus $3.9 \mathrm{~g}$ of $\mathrm{P} / 100 \mathrm{~g}$ of protein gain; NRC 1996), the basal diet $(0.15 \% \mathrm{P})$ provided $56 \%$ of $\mathrm{P}$ requirements. The basal diet was supplemented with monoammonium phosphate (MAP) to obtain dietary $\mathrm{P}$ concentration of $0.27,0.36$, and $0.45 \%$ to provide an estimated 100 , 133 , and $167 \%$ of the $\mathrm{P}$ requirement. Extra N provided with MAP supplementation was equalized among the treatment groups with trace amounts of urea. Steers were housed in individual stalls $(1.25 \times 2.25 \mathrm{~m})$ and fed once daily at $1200 \mathrm{~h}$ on $\mathrm{d} 1$ to 7 and 4 times daily at $0600,1200,1800$, and $2400 \mathrm{~h}$ on d 8 to 14 of each period. Steers had continuous access to feed and water during the experiment. Ytterbium-labeled corn silage (Harvatine et al., 2002) and Co-EDTA (Udén et al., 1980) were dosed at $120 \mathrm{mg} / \mathrm{d}$ as particulate and liquid phase markers, respectively, to estimate digesta flow. Markers were mixed into the TMR for dosing at each feeding on d 8 to 14 of each period.

Feed and feed refusals were sampled daily and stored at $-20^{\circ} \mathrm{C}$. Starting from $1800 \mathrm{~h}$ on d 11 of each period, approximately $200 \mathrm{~mL}$ of duodenal contents and 100 $\mathrm{mL}$ of ileal contents were collected from each steer every $9 \mathrm{~h}$, with sampling times advanced by $3 \mathrm{~h}$ each day to account for diurnal variation. Removal of the duodenal cannula plug often resulted in an initial surge of duodenal digesta. This initial surge was discarded and digesta from subsequent flow was retained and frozen at $-20^{\circ} \mathrm{C}$. Total fecal collection was conducted on d 11 to 14 of each period with fecal bags (Tolleson and Erlinger, 1989), and the bags were emptied twice daily. Fecal contents were thoroughly mixed daily, and a subsample was collected and frozen at $-20^{\circ} \mathrm{C}$. Blood samples were obtained on d 14 of each period from the coccygeal vessel and saved in Vacuette tubes (Greiner Bio-One, Monroe, NC). Serum was separated by centrifugation at $1,850 \times \mathrm{g}$ for $10 \mathrm{~min}$ at $4^{\circ} \mathrm{C}$ and stored at $-20^{\circ} \mathrm{C}$.

\section{Laboratory Analysis}

Feed, feed refusals, composited ileal samples (by steer within period), and fecal samples were thawed at room temperature, then dried at $55^{\circ} \mathrm{C}$ in a forced-air oven (Thermo Scientific Precision 645, Danville, IN) and ground through a 1-mm screen in a Wiley mill (Arthur H. Thomas, Philadelphia, PA). Ground feed and feed refusals were analyzed in duplicate for total Kjeldahl N (AOAC, 1984), NDF (heat-stable $\alpha$-amylase and $\mathrm{Na}_{2} \mathrm{SO}_{3}$ were used) and ADF according to Van Soest et al. (1991), total P and Pi using the yellow molybdo- 
vanadate method and molybdate blue method (AOAC, 1984), and Co and $\mathrm{Yb}$ using ICP-MS (Harvatine et al., 2002). Ground ileal and fecal samples were analyzed for total $\mathrm{P}, \mathrm{Pi}, \mathrm{Co}$, and $\mathrm{Yb}$ with the same methods as for feed and refusals.

Due to the nonhomogeneous nature of the duodenal digesta, the composited duodenal samples (by steer within period) were separated into 2 phases as described in Ahvenjärvi et al. (2000). Briefly, samples were centrifuged at $1,000 \times g\left(5^{\circ} \mathrm{C}, 5 \mathrm{~min}\right)$ and the supernatant was decanted and defined as the duodenal fluid phase. The pellet was defined as the duodenal particle phase. The separated phases were frozen, freeze-dried (FreezeZone Benchtop, Labconco, Kansas City, MO), and ground through a $1-\mathrm{mm}$ screen in a Wiley mill (Arthur H. Thomas, Philadelphia, PA) or freezer mill (SPEX 6850 Freezer Mill, SPEX CertiPrep Inc., Metuchen, NJ) for analysis of total P, Pi, Co, and $\mathrm{Yb}$ (same methods as described previously). Flow of $\mathrm{P}$ into and out of the small intestine was estimated with the double marker method presented in France and Siddons (1986). Concentration of serum Pi was analyzed by measuring the formed phosphomolybdate complex in a spectrophotometer (Eon Microplate Spectrophotometer; BioTek Instruments Inc., Winooski, VT).

\section{Statistical Analysis}

Data analysis was performed using PROC GLIMMIX in SAS (SAS Institute, 2008). The effects of treatment, period, square, and interaction of treatment and square were included in the model as fixed effects. Preplanned contrasts were used to evaluate linear and quadratic treatment effects. Due to the unequal space between the treatments (dietary P \%), the polynomial coefficients for the linear and quadratic effects were obtained with PROC IML. Differences were declared significant at $P$ $<0.05$ and trends at $P<0.10$. Results were reported as least squares means.

\section{RESULTS AND DISCUSSION}

\section{Diets, DMI, and Digestibility}

Ingredient and nutrient composition of diets are listed in Table 1. Dietary P did not affect intake of DM, NDF, or N (Table 2). In contrast, Wise et al. (1958) observed that in Holstein male calves (average BW $110.3 \pm 7.4$ $\mathrm{kg}$ ) feed consumption was directly related to dietary $\mathrm{P}$, with calves fed a low $\mathrm{P}$ diet (45\% of $\mathrm{P}$ requirement) consuming about $78 \%$ of the feed consumed by calves fed sufficient P. Similarly, Gartner (1982) found that feed intake of Hereford heifers $(378 \pm 21.4 \mathrm{~kg})$ was reduced by $13 \%$ when diet providing $50 \%$ of the $\mathrm{P}$ requirement as compared with $100 \%$ of requirement. In Holstein bull calves, increasing dietary $\mathrm{P}$ from 0.26 to $0.34 \%$ increased feed intake, but no further increase was observed from 0.34 to $0.41 \%$ (Jackson et al., 1988). The decreased DMI at very low $\mathrm{P}$ intake is usually attributed to compromised rumen microbial function.

Dry matter digestibility had a tendency to be different $(P=0.07)$, increasing slightly in steers fed $0.27 \% \mathrm{P}$. Although $\mathrm{P}$ is required by rumen microbes for efficient cellulose digestion (Field et al., 1983), the reason for

Table 1. Ingredient and nutrient composition of diet

\begin{tabular}{|c|c|c|c|c|}
\hline \multirow[b]{2}{*}{ Item } & \multicolumn{4}{|c|}{$\mathrm{P}, \%$ of $\mathrm{DM}$} \\
\hline & 0.15 & 0.27 & 0.36 & 0.45 \\
\hline \multicolumn{5}{|l|}{ Ingredient, \% of DM } \\
\hline Beet pulp, dehydrated & 40.83 & 40.72 & 40.6 & 40.5 \\
\hline Corn silage & 30.91 & 30.83 & 30.72 & 30.65 \\
\hline Corn & 15.95 & 15.91 & 15.86 & 15.82 \\
\hline Molasses, dehydrated & 4.99 & 4.97 & 4.96 & 4.95 \\
\hline Megalac $^{1}$ & 4.99 & 4.97 & 4.96 & 4.95 \\
\hline Urea & 1.88 & 1.71 & 1.68 & 1.58 \\
\hline Vitamin $\mathrm{ADE}^{2}$ & 0.25 & 0.25 & 0.25 & 0.25 \\
\hline Trace mineral salt ${ }^{3}$ & 0.2 & 0.2 & 0.2 & 0.2 \\
\hline Monoammonium phosphate & 0 & 0.44 & 0.77 & 1.1 \\
\hline \multicolumn{5}{|l|}{ Nutrient, $\%$ of DM } \\
\hline $\mathrm{DM}$ & 60.7 & 60.7 & 60.7 & 60.7 \\
\hline $\mathrm{CP}$ & 12.6 & 12.6 & 12.6 & 12.6 \\
\hline $\mathrm{NDF}$ & 32.1 & 32.1 & 32.1 & 32.1 \\
\hline $\mathrm{ADF}$ & 18.2 & 18.2 & 18.2 & 18.2 \\
\hline $\mathrm{P}$ & 0.15 & 0.27 & 0.36 & 0.45 \\
\hline
\end{tabular}


Table 2. Effect of dietary P content on DMI and digestibility

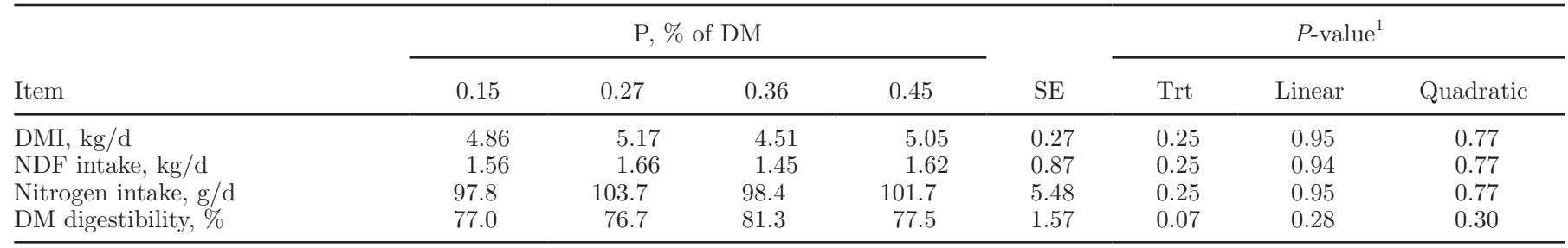

${ }^{1} P$-values for treatment (Trt), linear, and quadratic effects.

elevation in DMD at this mid-range treatment (rather than simply a depression at low $\mathrm{P}$ compared with all others) was unclear. Chicco et al. (1965) suggested that at least $60 \mathrm{mg}$ of available $\mathrm{P}$ per liter of medium was required to maximize cellulose disappearance. In a continuous rumen incubation system, cellulose digestion and VFA production decreased when Pi concentration was lowered to $0.1 \mathrm{mM}$, whereas microbial protein synthesis was reduced at $\mathrm{Pi}$ concentrations of less than $0.03 \mathrm{~m} M$ (Komisarczuk et al., 1987). These changes in microbial metabolism need to be considered when interpreting the effects of $\mathrm{P}$ deficiency. In the current study, the lack of clear detrimental effects of low $\mathrm{P}$ intake maybe due to the short duration of the study. In the short term, bone mobilization may ameliorate the low $\mathrm{P}$ concentration in the plasma to minimize the side effects of low dietary P. This is similar to observations in studies with lactating cows (Guyton et al., 2003; Puggaard et al., 2011) and steers (Erickson et al., 2002). In studies showing negative effects, the P supply was extremely low (45\% of $\mathrm{P}$ requirement; Wise et al., 1958) or the deficiency was over an extended period of time (lactating cows fed $0.31 \% \mathrm{P}$ for 2 to 3 lactations; Wu et al., 2001).

\section{Digestion and Absorption of $P$ in the Digestive Tract}

$P$ Intake and Digestibility. As expected, intake of total $\mathrm{P}$ and $\mathrm{Pi}$ were linearly increased with increasing dietary P (Table 3 ). Dietary P had a quadratic effect on apparent $\mathrm{P}$ digestibility, with steers fed the basal diet $(0.15 \% \mathrm{P})$ having the lowest apparent $\mathrm{P}$ digestibility $(21.9,51.4,57.5$, and $59.5 \% ; P<0.01)$. Reduced apparent $\mathrm{P}$ digestibility at higher $\mathrm{P}$ intake is the more usual observation but is not universal (Guyton et al., 2003). Geisert et al. (2010) observed that steers fed diets with $0.12 \% \mathrm{P}$ had apparent $\mathrm{P}$ digestibility of just 11.3\%. Ternouth (1990) suggested that slight reduction in apparent $\mathrm{P}$ digestibility at low $\mathrm{P}$ intake may be due to compromised microbes in the cecum/colon rather than the rumen; it is relatively difficult to reduce ruminal $\mathrm{P}$ concentration enough to depress microbial activity there. Another explanation is that salivary $\mathrm{P}$ was a greater proportion of $\mathrm{P}$ entering the digestive tract in this treatment. This could reduce the estimate of apparent digestibility of dietary P.

$P$ Absorption from the Small Intestine. Because of salivary $\mathrm{P}$ recycling, duodenal $\mathrm{P}$ flows were greater than $\mathrm{P}$ intake in all treatment groups (Table 3). Total $\mathrm{P}$ absorbed from the small intestine was linearly increased with increasing $\mathrm{P}$ flow to the duodenum with absorbed $\mathrm{P}$ as a proportion of duodenal $\mathrm{P}$ flow unaffected (Table 3). The mechanisms of $\mathrm{P}$ absorption are little studied in ruminants. In monogastrics, Breves and Schroder (1991) reported 2 mechanisms of $\mathrm{P}$ transport in the small intestine: a passive nonsaturable mechanism and a secondary, active Na-coupled mechanism that is controlled by $1,25-(\mathrm{OH})_{2} \mathrm{D}_{3}$. Sabbagh et al. (2009) clarified this, observing that in mice, intestinal phosphate absorption occurs through both a paracellular mechanism involving tight junctions and an active transcellular mechanism involving the type- 2 sodium-dependent phosphate co-transporter. In sheep, the upper small intestine is the major absorptive site with both active transport and passive diffusion mechanisms (Care, 1994). With perfusion of the temporarily isolated upper small intestine with $\mathrm{NaH}_{2} \mathrm{PO}_{4}$ (5 to 50 $\mathrm{mmol} / \mathrm{L}$ ), Scott et al. (1984) reported a curvilinear relationship between $\mathrm{P}$ absorption and $\mathrm{P}$ concentration; absorption efficiency fell from 0.74 at $5 \mathrm{mmol} / \mathrm{L}$ to 0.35 at $50 \mathrm{mmol} / \mathrm{L}$. It was also reported that in sheep, as dietary P increased from 2.5 to $5.0 \mathrm{~g} / \mathrm{kg}$ of DM, total $\mathrm{P}$ absorbed increased but efficiency of absorption was constant (Bravo et al., 2003a,b). Combined, these studies support the conclusion that, in general, increasing $\mathrm{P}$ flow into the duodenum increases $\mathrm{P}$ absorption without changes in absorption efficiency. Under higher dietary $\mathrm{P}$ intake, high blood $\mathrm{P}$ concentration could slow down the passive transport and the upper limit of active transport could also be saturated.

$\boldsymbol{P}$ Absorption from the Large Intestine. No effect of dietary $\mathrm{P}$ on $\mathrm{P}$ absorption in large intestine was observed and net secretion was observed for all treatments (Table 3). This is likely due to the microbial degradation of organic $\mathrm{P}$ compounds or degradation of microbial $\mathrm{P}$ in large intestine, or both. In ruminants, the 
Table 3. Effect of dietary $\mathrm{P}$ content on intake and absorption of total $\mathrm{P}$ and inorganic $\mathrm{P}(\mathrm{Pi})$

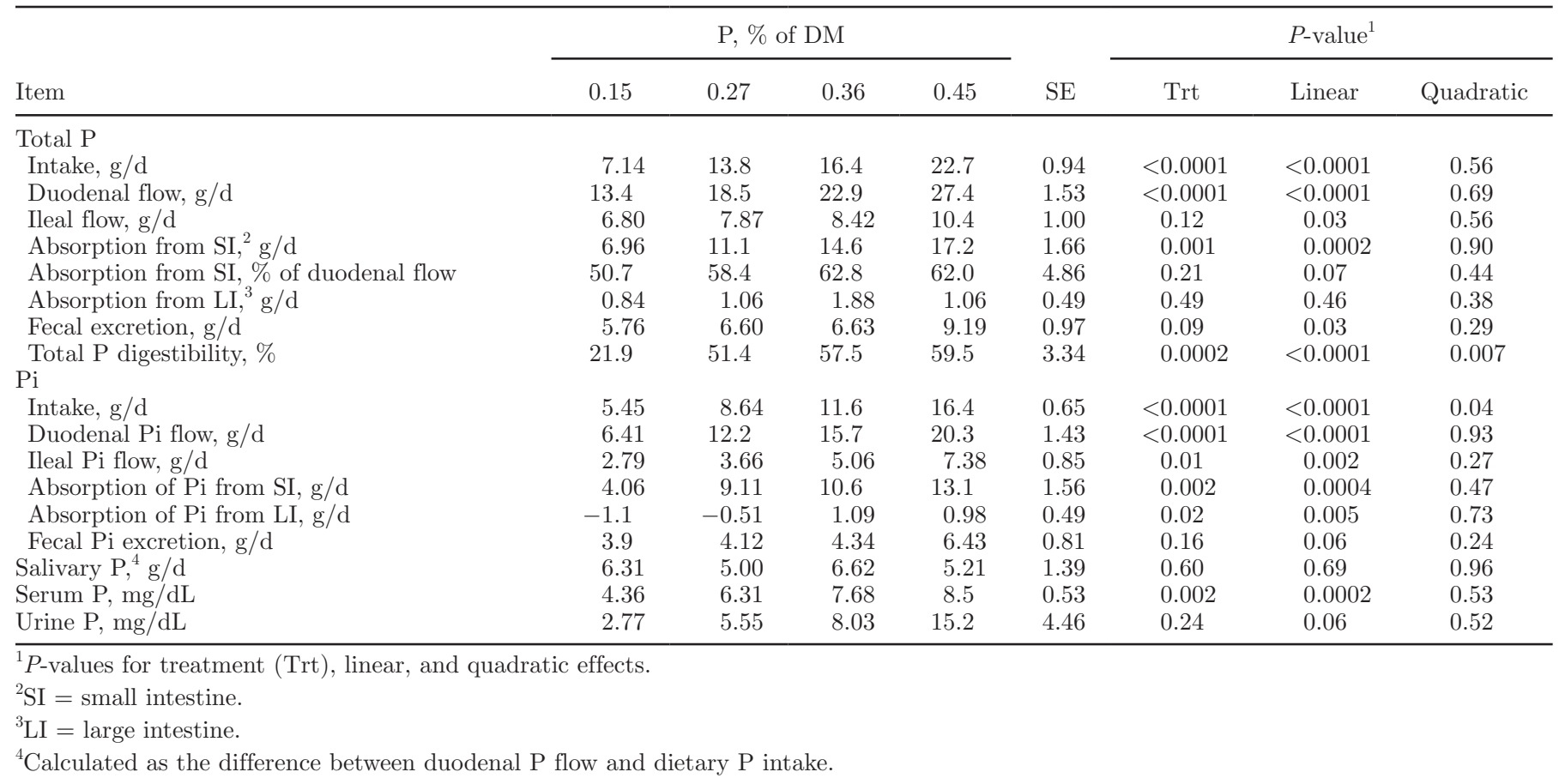

large intestine plays a much smaller role in $\mathrm{P}$ absorption than the small intestine. Some evidence, however, indicates that the colon may be an important site for $\mathrm{P}$ absorption in preweaned ruminants. Scharrer (1985) observed the same phosphate absorption efficiency from the descending colon as the upper and mid-jejunum in young lambs.

\section{Fecal P Excretion}

Total fecal $\mathrm{P}$ excretion tended to increase linearly with increasing dietary $\mathrm{P}$ intake (Table 3). Increased fecal $\mathrm{P}$ excretion with increasing dietary $\mathrm{P}$ has been reported in lactating dairy cows (Wu et al., 2000; Knowlton and Herbein, 2002) and steers (Geisert et al., 2010). Interestingly, Witt and Owens (1983) reported that 2 out of 6 steers fed a low $\mathrm{P}$ diet $(0.12 \%)$ excreted more $\mathrm{P}$ in feces than they consumed during short period of $\mathrm{P}$ deficiency. This implies that bone $\mathrm{P}$ or tissue $\mathrm{P}$ may be mobilized allowing the animal to endure intermittent periods of $\mathrm{P}$ deficiency.

\section{Salivary P Secretion}

In the current study, salivary $\mathrm{P}$ was not affected by treatment (Table 3). Salivary $\mathrm{P}$ was estimated as the difference between duodenal $\mathrm{P}$ flow and $\mathrm{P}$ intake (Scott et al., 1984, 1985; Scott and Buchan, 1987). In monogastrics, the kidneys are most important in removing excess $\mathrm{P}$ from the blood, whereas, in ruminants, the salivary glands play this role (Care, 1994). The salivary glands of cattle can concentrate plasma $\mathrm{P}$ from 3- to 8 -fold depending on salivary flow rate and plasma $\mathrm{P}$ concentration (Ternouth et al., 1985). Low P intake does not necessarily result in low salivary $\mathrm{P}$ secretion. Puggaard et al. (2011) demonstrated that low P intake $(0.24 \%)$ did not diminish salivary $\mathrm{P}$ flux in lactating dairy cows, suggesting that rumen microbe function was prioritized at low $\mathrm{P}$ intake with bone $\mathrm{P}$ probably mobilized to maintain salivary $\mathrm{P}$ recycling. The results of the current study are consistent with this "rumen support" theory of Puggaard et al. (2011).

\section{Serum Pi and Urinary $P$}

Consistent with most reports (Wu et al., 2000; Puggaard et al., 2011), serum Pi concentration at low P intake was depressed compared with higher $\mathrm{P}$ intake and increased linearly with increasing $\mathrm{P}$ intake (Table 3). Serum Pi less than $4 \mathrm{mg} / \mathrm{dL}$ is generally seen as an indicator of $\mathrm{P}$ deficiency (Erickson et al., 2002). By mobilizing $\mathrm{P}$ from bone, ruminants appear to have the ability to buffer effects of dietary $\mathrm{P}$ on the blood $\mathrm{P}$ pool.

Urinary $\mathrm{P}$ concentrations were unaffected by treatment $(P=0.24$, Table 3$)$ but tended to increase with increasing dietary $\mathrm{P}$ intake $(P=0.06$, Table 3$)$. Due to experimental limitations (no total collection of urine), 
urinary P excretion could not be calculated. Observed urinary $\mathrm{P}$ concentrations were in the range of that observed in heifers (average 0.88 to $16.47 \mathrm{mg} / \mathrm{dL}$; unpublished data from other studies in our laboratory). Urinary $\mathrm{P}$ excretion is highly variable among different species and between animals in the same species (3.4 to $18.2 \mathrm{~g} / \mathrm{d}$; Geisert et al., 2010). In dairy cattle, urinary $\mathrm{P}$ excretion is negligible compared with fecal $\mathrm{P}$ excretion (Puggaard et al., 2011) and the kidneys do not contribute significantly to the overall regulation of $\mathrm{P}$ homeostasis in ruminants (Breves and Schroder (1991).

\section{CONCLUSIONS}

Absorption efficiency of $\mathrm{P}$ from the small intestine by growing Holstein steers on a high beet pulp diet supplemented with MAP was unchanged despite the short-term $\mathrm{P}$ deficiency suggested by reduced serum Pi. Likewise, salivary P secretion was unchanged. Thus we conclude that rumen function was prioritized over maintenance of blood $\mathrm{P}$. These results shed light on mechanisms of control of $\mathrm{P}$ homeostasis in the face of short-term $\mathrm{P}$ deficiency.

\section{ACKNOWLEDGMENTS}

Funding for this work was provided, in part, by the Virginia Agricultural Experiment Station (Blacksburg, VA) and the Hatch Program of the National Institute of Food and Agriculture, US Department of Agriculture (Washington, DC). Author Xin Feng received fellowship support from the John Lee Pratt Foundation.

\section{REFERENCES}

Ahvenjärvi, S., A. Vanhatalo, P. Huhtanen, and T. Varvikko. 2000. Determination of reticulo-rumen and whole stomach digestion in lactating cows by omasal canal or duodenal sampling. Br. J. Nutr. 83:67-77.

AOAC. 1984. Official Methods of Analysis. 14th ed. Assoc. Off. Anal. Chem., Arlington, VA.

Bravo, D., C. Bogaert, F. Meschy, and D. Sauvant. 2003a. Plasma phosphorus content and dietary phosphorus availability in adult sheep. Anim. Res. 52:427-435.

Bravo, D., D. Sauvant, C. Bogaert, and F. Meschy. 2003b. Quantitative aspects of phosphorus excretion in ruminants. Reprod. Nutr. Dev. 43:285-300.

Breves, G., R. Ross, and H. Holler. 1985. Dietary phosphorus depletion in sheep: Effects on plasma inorganic phosphorus, calcium, 1,25- $(\mathrm{OH})_{2}$-Vit. $\mathrm{D}_{3}$ and alkaline phosphatase and on gastrointestinal $\mathrm{P}$ and Ca balances. J. Agric. Sci. 105:623-629.

Breves, G., and B. Schroder. 1991. Comparative aspects of gastrointestinal phosphorus metabolism. Nutr. Res. Rev. 4:125-140.

Care, A. D. 1994. The absorption of phosphate from the digestive tract of ruminant animals. Br. Vet. J. 150:197-205.

Care, A. D., J. P. Barlet, and H. M. Abdel-Hafeez. 1980. Calcium and phosphorus homeostasis in ruminants and its relationship to the etiology and prevention of parturient paresis. Pages 429-446 in
Proc. 5th Int. Symp. Ruminant Physiology. Y. Ruckebusch and P. Thivend, ed. MTP Press, Lancaster, UK.

Chicco, C. F., C. B. Ammerman, J. E. Moore, W. Von, L. R. Arrington, and R. L. Shirley. 1965. Utilization of inorganic ortho-, meta- and pyrophosphates by lambs and by cellulolytic rumen microorganisms in vitro. J. Anim. Sci. 24:355-363.

Erickson, G. E., T. J. Klopfenstein, C. T. Milton, D. Brink, M. W. Orth, and K. M. Whittet. 2002. Phosphorus requirement of finishing feedlot calves. J. Anim. Sci. 80:1690-1695.

Erickson, G. E., T. J. Klopfenstein, C. T. Milton, D. Hanson, and C. Calkins. 1999. Effect of dietary phosphorus on finishing steer performance, bone status, and carcass maturity. J. Anim. Sci. $77: 2832-2836$.

Field, A. C., J. Kamphues, and J. A. Woolliams. 1983. The effect of dietary intake of calcium and phosphorus on the absorption and excretion of phosphorus in chimaera-derived sheep. J. Agric. Sci. 101:597-602.

France, J., and R. C. Siddons. 1986. Determination of digesta flow by continuous marker infusion. J. Theor. Biol. 121:105-119.

Gartner, R. J. W. 1982. Effect of induced, subclinical phosphorus deficiency on feed intake and growth of beef heifers. J. Agric. Sci. 98:23-29.

Geisert, B. G., G. E. Erickson, T. J. Klopfenstein, C. N. Macken, M. K. Luebbe, and J. C. MacDonald. 2010. Phosphorus requirement and excretion of finishing beef cattle fed different concentrations of phosphorus. J. Anim. Sci. 88:2393-2402.

Guyton, A. D., J. M. McKinney, and K. F. Knowlton. 2003. The effect of steam-flaked or dry ground corn and supplemental phytic acid on phosphorus partitioning and ruminal phytase activity in lactating cows. J. Dairy Sci. 86:3972-3982.

Harvatine, D. I., J. E. Winkler, M. Devant-Guille, J. L. Firkins, N. R. St-Pierre, B. S. Oldick, and M. L. Eastridge. 2002. Whole linted cottonseed as a forage substitute: Fiber effectiveness and digestion kinetics. J. Dairy Sci. 85:1988-1999.

Holler, H., A. Figge, J. Richter, and G. Breves. 1988. Calcium and inorganic phosphate net absorption from the sheep colon and rectum perfused in vivo. J. Anim. Physiol. Anim. Nutr. (Berl.) 59:9-15.

Jackson, J. A., D. L. Langer, and R. W. Hemken. 1988. Evaluation of content and source of phosphorus fed to dairy calves. J. Dairy Sci. $71: 2187-2192$.

Knowlton, K. F., and J. H. Herbein. 2002. Phosphorus partitioning during early lactation in dairy cows fed diets varying in phosphorus content. J. Dairy Sci. 85:1227-1236.

Komisarczuk, S., R. J. Merry, and A. B. McAllan. 1987. Effect of different levels of phosphorus on rumen microbial fermentation and synthesis determined using a continuous culture technique. Br. J. Nutr. 57:279-290.

NRC. 1996. Nutrient Requirements of Beef Cattle. 7th rev. ed. Natl. Acad. Press, Washington, DC.

NRC. 2001. Nutrient Requirements of Dairy Cattle. 7th rev. ed. Natl. Acad. Press, Washington, DC.

Puggaard, L., N. B. Kristensen, and J. Sehested. 2011. Effect of decreasing dietary phosphorus supply on net recycling of inorganic phosphate in lactating dairy cows. J. Dairy Sci. 94:1420-1429.

Ray, P. P., J. Jarrett, and K. F. Knowlton. 2013. Effect of dietary phytate on phosphorus digestibility in dairy cows. J. Dairy Sci. 96:1156-1163.

Sabbagh, Y., S. P. O'Brien, W. P. Song, J. H. Boulanger, A. Stockmann, C. Arbeeny, and S. C. Schiavi. 2009. Intestinal Npt2b plays a major role in phosphate absorption and homeostasis. J. Am. Soc. Nephrol. 20:2348-2358.

SAS Institute. 2008. SAS/Stat ${ }^{\circledR} 9.2$ User's Guide. SAS Institute Inc., Cary, NC.

Scharrer, E. 1985. Phosphate absorption at different intestinal sites in the developing lamb. Q. J. Exp. Physiol. 70:615-621.

Scott, D., and W. Buchan. 1987. The effects of feeding either hay or grass diets on salivary phosphorus secretion, net intestinal phosphorus absorption and on the partition of phosphorus excretion between urine and feces in the sheep. Q. J. Exp. Physiol. 72:331338. 
Scott, D., A. F. McLean, and W. Buchan. 1984. The effect of variation in phosphorus intake on net intestinal phosphorus absorption, salivary phosphorus secretion and pathway of excretion in sheep fed roughage diets. Q. J. Exp. Physiol. 69:439-452.

Scott, D., F. G. Whitelaw, W. Buchan, and L. A. Bruce. 1985. The effect of variation in phosphorus intake on salivary phosphorus secretion, net intestinal phosphorus absorption and faecal endogenous phosphorus excretion in sheep. J. Agric. Sci. 105:271-277.

Ternouth, J. H. 1990. Phosphorus and beef production in northern Australia. 3. Phosphorus in cattle-A review. Trop. Grassl. 24:159-169.

Ternouth, J. H., H. M. S. Davies, J. T. B. Milton, M. W. Simpsonmorgan, and N. E. Sands. 1985. Phosphorus-metabolism in ruminants.1. Techniques for phosphorus depletion. Aust. J. Agric. Res. 36:637-645.

Tolleson, D. R., and L. L. Erlinger. 1989. An improved harness for securing fecal collection bags to grazing cattle. J. Range Manage. 42:396-399.

Udén, P., P. E. Colucci, and P. J. Vansoest. 1980. Investigation of chromium, cerium and cobalt as markers in digesta-Rate of passage studies. J. Sci. Food Agric. 31:625-632.
Van Soest, P. J., J. B. Robertson, and B. A. Lewis. 1991. Methods for dietary fiber, neutral detergent fiber, and nonstarch polysaccharides in relation to animal nutrition. J. Dairy Sci. 74:3583-3597.

Wasserman, R. H., and A. N. Taylor. 1976. Gastrointestinal absorption of calcium and phosphate. Handbook of physiology. Sec. 7: Endocrinology. Vol. VII, Parathyroid Gland. Am. Physiol. Soc., Washington, DC

Wise, M. B., S. E. Smith, and L. L. Barns. 1958. The phosphorus requirements of calves. J. Anim. Sci. 17:89-99.

Witt, K. E., and F. N. Owens. 1983. Phosphorus: Ruminal availability and effects on digestion. J. Anim. Sci. 56:930-937.

Wu, Z., L. D. Satter, A. J. Blohowiak, R. H. Stauffacher, and J. H. Wilson. 2001. Milk production, estimated phosphorus excretion, and bone characteristics of dairy cows fed different amounts of phosphorus for two or three years. J. Dairy Sci. 84:1738-1748.

Wu, Z., L. D. Satter, and R. Sojo. 2000. Milk production, reproductive performance, and fecal excretion of phosphorus by dairy cows fed three amounts of phosphorus. J. Dairy Sci. 83:1028-1041.

Wu, Z., S. K. Tallam, V. A. Ishler, and D. D. Archibald. 2003. Utilization of phosphorus in lactating cows fed varying amounts of phosphorus and forage. J. Dairy Sci. 86:3300-3308. 